\title{
Geniş Kapsamlı Finansal Gelişmişlik Endeksi İle Türkiye'nin Finansal Gelişmişliğinin Tespiti ve Gelişmekte Olan Ülkeler İle Karşılaştırılması \\ (Measuring Financial Development of Turkey With Broad-Based Index And Comparison With Other Developing Countries)
}

\section{Doğuş EMIN iD a}

a Ankara Sosyal Bilimler Üniversitesi, Siyasal Bilgiler Fakültesi, İşletme Bölümü, Ankara, Türkiye. dogus.emin@asbu.edu.tr

\begin{tabular}{|c|c|}
\hline MAK & ZET \\
\hline $\begin{array}{l}\text { Anahtar Kelimeler: } \\
\text { Finansal Gelişme } \\
\text { IMF Finansal Gelişmişlik } \\
\text { Endeksi } \\
\text { Gelişmekte olan Ülkeler } \\
\text { Finansal Piyasalar }\end{array}$ & $\begin{array}{l}\text { Amaç - Bu çalışmada öncelikli olarak Türkiye'nin finansal gelişiminin tespit edilmesi } \\
\text { amaçlanmaktadır. Bu bağlamda IMF çalışanları tarafından } 2016 \text { yılında tanıtılan "Geniş Kapsaml } \\
\text { Finansal Gelişmişlik Endeksi" literatürde Türkiye için son } 12 \text { yıllık süreç göz önünde } \\
\text { bulundurularak ilk defa kullanılacaktır. İkinci basamakta ise benzer ekonomik dinamiklere sahip } \\
\text { olmaları sebebiyle yatırımcılar ve profesyoneller tarafından sürekli olarak Türkiye'nin } \\
\text { karşılaştırıldığı Brezilya, Güney Afrika, Malezya ve Polonya için gelişmişlik endeksleri } \\
\text { hesaplanarak sonuçlar karşılaştırlacaktır. }\end{array}$ \\
\hline $\begin{array}{l}\text { Gönderilme Tarihi } 8 \text { Ağustos } \\
2019 \\
\text { Revizyon Tarihi } 15 \text { Eylül } 2019 \\
\text { Kabul Tarihi } 20 \text { Eylül } 2019\end{array}$ & $\begin{array}{l}\text { Yöntem - Bu çalışmada finansal gelişmişliğin farklı boyutlarını inceleyen } 9 \text { adet endeks Temel } \\
\text { Bileşenler Analizi kullanılarak hem finansal kurumların hem de finansal piyasaların derinlik, } \\
\text { erişilebilirlik ve verimliliklerini belirleyen } 6 \text { alt endeks ile oluşturulacaktır. İkinci adımda bu alt } \\
\text { endeksler finansal kurumlar ve finansal piyasalar olmak üzere iki endeks altında bir araya } \\
\text { getirilerek nihai gelişmişlik endeksi oluşturulacaktır. Finansal kurumların derinlik endeksinin } \\
\text { oluşturulması için 4, erişilebilirlik endeksinin oluşturulması için } 2 \text {, verimlilik endeksinin } \\
\text { oluşturulması için 6; finansal piyasaların derinlik endeksinin oluşturulması için 5, erişilebilirlik } \\
\text { endeksinin oluşturulması için } 2 \text { ve verimlilik endeksinin oluşturulması için } 1 \text { olmak üzere toplamda } \\
20 \text { değişken incelenecektir. }\end{array}$ \\
\hline
\end{tabular}

Bulgular - Finansal kurumlar ve finansal piyasalar endekslerinin bir araya getirilmesi ile elde edilen Finansal Gelişmişlik Endeksi incelenen beş ülkenin nihai olarak finansal gelişmişlik derecelerini ve sıralamalarını ortaya çıkarmıştır. Buna göre Malezya incelenen beş gelişmekte olan ülke arasında finansal gelişmişliği en yüksek ülke olarak belirlenirken Malezya'yı Türkiye takip etmiştir. Geri kalan üç ülke arasında sıralama ise Brezilya, Güney Afrika ve Polonya şeklinde olmuştur.

Tartışma - Türkiye'nin finansal gelişiminin en yeni ve kapsamlı endeksin kullanılması ile tespit edilmesi ve gelişmekte olan ülkeler arasındaki yerinin belirlenmesi ile birlikte hem politika yapıcılara yol gösterici hem de hesaplanan endeksin daha mikro ölçekte analizlere tabi tutulması ile ortaya çıkabilecek birçok çalışmaya öncü temel bir çalışma ortaya konmuştur.

\begin{tabular}{|c|c|}
\hline ARTICLE INFO & ABSTRACT \\
\hline $\begin{array}{l}\text { Keywords: } \\
\text { Financial Development } \\
\text { IMF Financial Development } \\
\text { Index } \\
\text { Emerging Markets } \\
\text { Financial Markets }\end{array}$ & $\begin{array}{l}\text { Purpose - This study primarily aims to determine Turkey's financial development. In this context, } \\
\text { the "broad-based index of financial development", which is introduced by IMF, is used for Turkey } \\
\text { for the last } 12 \text { years period for the first time. In the second stage of the study, the development index } \\
\text { is calculated for a group of developing countries which are compared with Turkish economy due to } \\
\text { their similarities in fundamental dynamics, namely Brazil, Malaysia, Poland and South Africa and } \\
\text { eventually the results will be compared. }\end{array}$ \\
\hline $\begin{array}{l}\text { Received } 8 \text { August } 2019 \\
\text { Revised } 15 \text { September } 2019 \\
\text { Accepted } 20 \text { September } 2019 \\
\text { Article Classification: } \\
\text { Research Article }\end{array}$ & $\begin{array}{l}\text { Design/Methodology/Approach - In this study, in total, } 9 \text { indices are constructed in order to } \\
\text { examine different dimensions of financial development. Primarily, six sub-indices are constructed } \\
\text { to determine the depth, access and efficiency of both financial institutions and financial markets. In } \\
\text { the second step, these indices are aggregated into two indices under financial institutions and } \\
\text { financial markets. In the last step, these two indices are used to form the final development index to } \\
\text { identify the financial development levels of Turkey and four other developing countries. To be able } \\
\text { to construct the financial institutions depth index } 4 \text {, for the access index } 2 \text {, for the efficiency index } 6 \text {; } \\
\text { for financial markets depth index 5, for access index } 2 \text { and for efficiency index } 1 \text {, in total } 20 \\
\text { explanatory variables are examined. }\end{array}$ \\
\hline & $\begin{array}{l}\text { Findings - Financial Development Index which is obtained by aggregation of indices for financial } \\
\text { institutions and financial markets finally reveals the level and the order of financial development of } \\
\text { the five developing countries. According to that while Malaysia is the most financially developed }\end{array}$ \\
\hline
\end{tabular}


country, Turkey is in the second rank. The rest of the examined countries are ordered as Brazil, South Africa and Poland.

Discussion - As a result of determination of financial development level of Turkey and its rank among other developing countries with the newest and broadest index, this study may play a road map role to policy makers. Furthermore, this study my easily be a pioneer and fundamental study as the indices that were constructed and calculated in this study are open to further micro level analyses.

\section{1- GíRIŞ}

Küreselleşme ile birlikte finansal sistemlerin ülke ekonomilerindeki rolü ve ağırlığı çok önemli boyutlara ulaşmıştır. Finans piyasalarında başlayan ve neredeyse bütün gelişmiş, ülke ekonomilerini derinden yaralayan 2008 yılındaki global kriz, finansal sistemin dünya ve ülke ekonomilerinde ne derece büyük öneme sahip olduğunu başlı başına gösteren acı bir ders olmuştur. Genel kanıya göre finansal sistemin gelişmesi uzun dönemde ekonomik büyüme ve kalkınmaya olumlu yönde etki etmektedir. Fakat ülkede yaşanabilecek herhangi bir makroekonomik istikrarsızlığın finansal gelişmenin olumlu etkilerini negatife çevirme ve ekonomik büyümede olumsuz sonuçlar ortaya çıkarma ihtimali vardır. Öte yandan hızla gelişen finansal sistemin ülkenin makro dinamiklerine olumlu katkıda bulunup ülkenin hızla büyümesinde etkin rol oynama olasılığ 1 da yüksektir. Yani, Türkiye gibi gelişmekte olan ülkelerde hem makroekonomik durum hem de finansal gelişmişlik derecesi ülkenin ekonomik durumu açısından eşit derecede öneme sahiptir.

Literatürde finansal gelişmişliğin ekonomik büyüme, eşitsizlik ve ekonomik istikrar üzerindeki etkileri geniş, çapta çalışılmış, ve bu alanlarda olumlu etkileri tespit edilmiştir. Daha mikro bağlamda ise finansal gelişmiş̧liğin net tasarruflar, üretken yatırımlara ayrılan sermaye miktarı, yatırımların gözlemlenmesi, risk çeşitlendirmesi ve mal ve hizmetlerin ticaretinde olumlu etkilerinin olduğu ortaya çıkmıştır (bkz. Levine, 2005, Demirgüç-Kunt ve Levine, 2009, ve Dabla-Norris ve Srivisal, 2013). Finansal gelişmişliğin ekonomide bu derece önemli rol oynaması akademisyenlerin de konuya olan ilgilerini artırmış, ve ülkelerin finansal gelişmişliklerini belirleyebilmek amacıyla farklı pratik metodolojiler oluşturulmuştur. Sonuç olarak bugün literatürde temsil yetenekleri ve isabet oranları farklılıklar gösteren birçok model yer almaktadır.

Finansal gelişmişliğin literatürde popülerlik kazandığı 1970'li yıllardan beri yapılan ampirik çalışmaların çoğunda (bkz. Rajan ve Zingales, 1998, Arcand vd., 2012, Dabla-Norris ve Srivisal, 2013) ülkelerin finansal gelişmişliği finansal derinliğin en önemli göstergelerinden olan özel kredilerin GSYİH'ye oranı ve borsaların büyüklüğünün GSYİH'ye oranı ile ölçülmüş̧ür. Bu çalışmada finansal gelişmişliğin farklı boyutlarını inceleyen 9 adet endeks oluşturulacaktır. Bu bağlamda ilk olarak hem finansal kurumların hem de finansal piyasaların derinlik, erişim ve etkinliklerini belirleyen 6 alt endeks oluşturulacaktır. İkinci adımda bu alt endeksler finansal kurumlar ve finansal piyasalar olmak üzere iki endeks altında bir araya getirilecektir. Son adımda ise nihai gelişmişlik endeksini oluşturmak için bu iki endeks bir araya getirilecek ve Türkiye'nin ve diğer gelişmekte olan ülkelerin finansal gelişmişlik endeksleri elde edilecektir. Finansal kurumların derinlik endeksinin oluşturulması için 4, erişilebilirlik endeksinin oluşturulması için 2, verimlilik endeksinin oluşturulması için 6; finansal piyasaların derinlik endeksinin oluşturulması için 5, erişilebilirlik endeksinin oluşturulması için 2 ve verimlilik endeksinin oluşturulması için 1 olmak üzere toplamda 20 değişken incelenecektir.

Çalışmanın ikinci basamağında ise Türkiye'nin karşılaştırıldığı Brezilya, Güney Afrika, Malezya ve Polonya için gelişmişlik endeksleri hesaplanacak ve Türkiye ile karşılaştırılmaları yapılacaktır. Böylelikle Türkiye'nin finansal gelişiminin en yeni ve kapsamlı endeksin kullanılması ile tespit edilmesi ve gelişmekte olan ülkeler arasındaki yerinin belirlenmesi ile birlikte hem politika yapıcılara yol gösterici bir çalışma ortaya çıkacak, hem de hesaplanan endeksin daha mikro ölçekte analizlere tabi tutulması ile birlikte birçok çalışmaya öncü olunacaktır.

\section{2- LITTERATÜR İNCELEMESI}

Finans ve kalkınma arasındaki ilişki ekonomik literatürün en önemli konularından biri olarak öne çıkmaktadır. Temel olarak finansal gelişme, finansal enstrümanların, piyasaların ve aracıların; bilgi, uygulama ve işlem maliyetlerinin etkilerini iyileştirdiği zaman gerçekleşmektedir. Başka bir deyişle finansal gelişme, planlanmış yatırımlar hakkında önceden bilgi üretilmesi, yatırımların izlenmesi ve kurumsal yönetişimin 
uygulanması, riskin ticareti, çeşitlendirilmesi ve yönetimi, tasarrufların harekete geçirilmesi ve bir araya toplanması ve mal ve hizmet değişimi alanlarındaki gelişmeleri kapsamaktadır (Levine, 2005).

Finansal gelişmişliğin ekonomik büyüme üzerindeki etkisi hem ampirik hem de teorik literatür düzeyinde tartışmalı bir konudur. Finansal gelişmişlik ve ekonomik büyüme arasındaki korelasyon ve nedensellik ilişkisi, uzun yıllardır ekonomistler ve karar alıcılar tarafından incelenmekte ve sonuç olarak karşıt görüşler ortaya çıkmaktadır. Bazı ekonomistler, finansal gelişmişliğin ekonomik büyümenin sağlanabilmesi yolunda önemli bir faktör olduğunu savunurken, bazıları ise bu görüşe katılmamaktadır. Bu noktada, Apergis vd. (2007) yaptıkları çalışmada bu görüşleri dört düşünce okulunda sınıflandırmıştır. Buna göre, Schumpeter (1912) ve Hicks (1969) çalışmalarının öncülük ettiği ilk sınıf konuyu arz yönünden ele almıştır. Bu konuda yapılan ilk çalışmalardan birini ortaya koyan Schumpeter (1912), iyi fon sağlayan bir finansal sistemin, teknolojik yeniliği teşvik ederek toplam üretimi arttıracağını ve dolayısıyla ekonomik büyümeyi olumlu yönde etkileyeceğini öne sürmüştür. Hicks'e (1969) göre ise finansal kurumlar sermaye oluşumu yoluyla ekonomik büyümeye katkıda bulunmaktadır. Goldsmith (1969) ise yapmış olduğu çalışmada finansal aracılık hizmetlerindeki gelişmenin sermayenin verimliliğini artırdığını ve kişi başına düşen milli gelir ve finansal gelişme arasında pozitif yönlü bir ilişkinin var olduğunu ifade etmiştir. Buna ek olarak, Levine (1997) borsa ve kurumlarla birlikte finansal sektörün gelişmesinin ekonomik büyümede dikkate değer bir rol oynadığına dikkat çekmiştir. Cline (2010) ise çalışmasında finansal sektördeki iyileşmenin ekonominin çeşitli sektörlerinin gelişmesine neden olacağını savunmaktadır. İkinci düşünce okulu ise finansal gelişmenin ekonomideki reel gelişmelerin bir sonucu olduğunu savunmaktadır. Robinson (1952) çalışmasında finansal aracıların, büyümede nedensel bir etki yapmadığını söylemiştir. Yine aynı çalışmasında yazar piyasadaki finansal hizmetlerin bu hizmetlere olan talep sonucu ortaya çıktığını savunmaktadır. Buna göre, ekonomi büyüdügünde, finansal hizmetler için daha yüksek talebe yanıt olarak piyasada daha fazla finansal kurum, ürün ve hizmet ortaya çıkmaktadır. Bu sebeplerle, finansal kalkınmanın her zaman daha yüksek bir ekonomik büyüme anlamına gelmediği vurgulanmaktadır. Üçüncü düşünce okuluna göre ise finans ve büyüme arasında karşılıklı bir etkinin olduğu kabul edilmektedir. Luintel ve Khan (1999) bu alanda yaptıkları çalışmanın sonucunda finansal gelişme ile büyüme arasındaki iki yönlü nedensellik olduğunu göstermiştir. Dördüncü düşünce okuluna göre ise finansal kalkınma ile ekonomik büyüme arasında bir ilişki bulunmamaktadır. Lucas (1988) çalışmasında ekonomik büyümeyi açıklamada finansın rolünün abartıldığını ortaya koymuştur.

Finansal kalkınma ve ekonomik büyüme ilişkisine ek olarak, literatürde Türkiye'nin finansal gelişmişliğini ve makroekonomi ile olan ilişkilerini inceleyen bir takım çalışmalar mevcuttur. Ünalmış (2002) 1970 ve 2001 yılları arasını VAR ve VEC tekniği ile Türkiye'nin finansal gelişmişliği ve makroekonomik değişkenler arasındaki ilişkiyi incelemiştir. Çalışma kısa dönemde ekonomik büyümenin finansal gelişmeye neden olduğunu, uzun dönemde ise hem finansal gelişmeden ekonomik büyümeye hem de ekonomik büyümeden finansal gelişmeye iki yönlü bir nedensellik ilişkisinin olduğunu ortaya koymuştur.

Çetintaş ve Barışık (2003) 1989 ve 2000 yılları arasını Granger nedensellik metodunu kullanarak analiz etmiştir. Bankacılık sektörü ve sermaye piyasalarını birkaç değişken kullanarak temsil eden yazarlar, sermaye piyasası ve bankacılık sektöründeki gelişmelerin ekonomik büyümeye neden olduğu sonucuna ulaşmışlardır. Çetintaş ve Barışık (2003) gibi Granger nedensellik modelini 1970-2004 dönemi için kullanan Aslan ve Küçükaksoy (2006) finansal gelişmenin ekonomik büyümeyi tetiklediği yönündeki arz itişli hipotezi desteklemişlerdir.

Kar ve Ağır (2006) 1987 ve 2002 yılları arasını inceledikleri çalışmalarında Johansen eş bütünleşme testini kullanmışlardır. Çalışmanın sonucunda finansal gelişme ve sermaye piyasasındaki derinleşme ile ekonomik büyüme arasında pozitif bir ilişki olduğu, bankacılık sektörü ve sermaye piyasası arasındaki ilişkinin ise istatistiksel olarak anlamlı olamayacak kadar zayıf olduğu ortaya çıkmıştır.

Halıcıoğlu (2007) 1968 ile 2005 yılları arasındaki dönemde finansal gelişme ve ekonomik büyüme arasındaki ilişkiyi sınır testi ile analiz etmiş, kısa ve uzun vadede nedenselliğin yönünü tespit etmek amacı ile bütünleşik Granger nedensellik analizini kullanmıştır. Buna göre uzun vadede finansal gelişmenin ekonomik büyümeye neden olduğu sonucuna ulaşmıştır. Diğer yandan literatürde finansal gelişmenin ekonomik büyümeyi hangi kanallar vasıtası ile etkilediğini ortaya koyan çalışma sayısı oldukça sınırlıdır. 
King ve Levine (1993) 80 gelişmiş, ve gelişmekte olan ülke üzerinde yaptıkları çalışmalarında finansal gelişmenin ekonomik büyümeyi toplam faktör verimliliği ve sermaye birikimi kanallarıyla etkilediğini ortaya koymuşlardır. Beck vd. (2000) GMM modeli kullanarak 77 ülke üzerinde yaptıkları çalışmada finansal gelişmenin sermaye birikimi ve toplam faktör verimliliğini pozitif yönde etkilediğini ancak finansal gelişmenin farklı farklı göstergelerinin bu kanallar üzerinde etkili olduğunu ortaya koymuşlardır. Claderon ve Liu (2003) Geweke tekniğini kullanarak 109 ülke üzerinde yaptıkları çalışmalarında finansal büyümenin hem verimlilik hem de sermaye birikimi kanalları vasıtasıyla ekonomik büyümeyi etkilediği, fakat asıl etkili olan kanalın verimlilik olduğunu göstermişlerdir.

Finansal gelişmişlik aynı zamanda yukarıdaki çalışmalardan farklı olarak daha özelde de incelenmiş, ve birçok akademisyen finansal gelişmişlik derecesinin belirlenebilmesi için farklı modeller ortaya atmışlardır. 1970'li yıllardan itibaren ampirik literatür finansal gelişmişliğin belirlenmesinde finansal derinliğe 'vekil-proxy' olabilecek iki ana değişkeni kullanmışlardır; özel kredilerin GSYİH'ye oranı ve borsadaki şirketlerin toplam değerinin GSYİH'ye oranı. Arcand vd. (2012) ve Dabla-Norris ve Srivisal (2013) finansal gelişmişliğin en net ve basit şekilde özel kredilerin GSYİH'ye oranı ve borsadaki şirketlerin toplam değerinin GSYİH'ye oranı ile ölçüldüğüne karar vermişler ve çalışmalarını bu şekilde kurgulamışlardır.

Diğer grup akademisyenler bu değişkenlerin farklı versiyonlarını çalışmalarında kullanmışlar ve temsil yeteneği daha yüksek endeksler oluşturmaya çalışmışlardır. Rajan ve Zingales (1998) finansal gelişmişlik ve makroekonomi arasındaki ilişkiyi inceledikleri çalışmalarında endüstri düzeyinde değişkenleri de finansal gelişmişliği ölçen endekslerine dâhil etmişlerdir. Finansal sistemin hızla gelişmesi ve finansal kurumların sistemde daha etkin rol oynamaya başlaması ile birlikte finansal piyasaları ölçen değişkenlerin yanında finansal kurumları temsil eden değişkenler de kullanılmaya başlanmıştır (bkz. Cíhák vd. (2012) ve Aizenman vd. (2015)).

\section{3- VERI VE METODOLOJİ}

\subsection{Veri}

Bu çalışmada Türkiye ile birlikte Brezilya, Güney Afrika, Malezya ve Polonya'nın gelişmişlik seviyesi incelenmiştir. Son yıllardaki hızlı küreselleşme ve ülkelerin değişen politik yapıları göz önünde bulundurulduğunda finansal gelişmişliğin hesaplanması için kullanılacak verilerin çok eskiye gitmemesinin daha sağlıklı olacağı düşünülmüştür. Bu bağlamda bu gelişmekte olan 5 ülke için veri seti 2005 ile 2016 yılları arası için oluşturulmuştur.

Finansal kurumların derinlik endeksinin oluşturulması için 4, erişim endeksinin oluşturulması için 2, etkinlik endeksinin oluşturulması için 6; finansal piyasaların derinlik endeksinin oluşturulması için 5, erişim endeksinin oluşturulması için 2 ve etkinlik endeksinin oluşturulması için 1 olmak üzere toplamda 20 değişken incelenmiştir.

Tablo 1 çalışmada kullanılan değişkenleri göstermektedir. Buna göre, finansal kurumların alt endeksi olan derinlik endeksi, özel sektör kredilerinin GSYİH'ye oranı, emeklilik fonu varlıklarının GSYİH'ye oranı, yatırım fonu varlıklarının GSYİH'ye oranı, toplam sigorta primlerinin GSYİH'ye oranı değişkenlerini kapsamaktadır. Finansal kurumlar endeksinin erişilebilirlik alt endeksi her 100.000 yetişkin için banka şube sayısı ve her 100.000 yetişkin için ATM sayısı değişkenlerini içermektedir. Etkinlik alt endeksi ise net faiz marjı, kredi mevduat farkı, faiz dışı gelirin toplam gelire oranı, genel giderlerin toplam varlıklara oranı, aktif karlılık ve öz sermaye karlılık oranı değişkenlerinden oluşmaktadır. Finansal piyasalar endeksinin derinlik alt endeksi toplam hisse senedi piyasası hacminin GSYİH'ye oranı, hisse senetlerinin GSYİH'ye oranı, devletin yurtdışı borçlarının GSYIH'ye oranı, finansal olmayan şirketlerin toplam borcunun GSYIH'ye oranı değişkenlerini içermektedir. Erişilebilirlik alt endeksi ilk 10 en büyük hisse senedi dışarıda bırakıldıktan sonraki piyasa hacmi oranı, borç veren kuruluşların sayısı (yerli, yabancı, finansal ve finansal olmayan); etkinlik alt endeksi hisse senedi piyasası devir oranı (hisse senetlerinin piyasa hacmine oranı) değişkenlerinden oluşmaktadır. 
Tablo 1. Alt Endekslerin Oluşturulmasında Kullanılan Değişkenler

\begin{tabular}{|c|c|}
\hline \multicolumn{2}{|c|}{ Finansal Kurumlar } \\
\hline Derinlik & $\begin{array}{l}\text { Özel Sektör Kredilerinin GSYİH'ye oranı } \\
\text { Emeklilik Fonu Varlıklarının GSYİH'ye oranı } \\
\text { Yatırım Fonu Varlıklarının GSYİH'ye oranı } \\
\text { Toplam Sigorta Primlerinin GSYİH'ye Oranı }\end{array}$ \\
\hline Erişilebilirlik & $\begin{array}{l}\text { Her } 100.000 \text { yetişkin için banka şube sayısı } \\
\text { Her } 100.000 \text { yetişkin için ATM sayısı }\end{array}$ \\
\hline Verimlilik & $\begin{array}{l}\text { Net Faiz Marjı } \\
\text { Kredi Mevduat Farkı } \\
\text { Faiz dışı gelirin Toplam Gelire Oranı } \\
\text { Genel Giderlerin Toplam Varlıklara Oranı } \\
\text { Aktif Karlılık } \\
\text { Öz sermaye Karlılık Oranı }\end{array}$ \\
\hline \multicolumn{2}{|c|}{ Finansal Piyasalar } \\
\hline Derinlik & $\begin{array}{l}\text { Toplam Hisse Senedi Piyasası Hacminin GSYİH'ye Oranı } \\
\text { Hisse Senetlerinin GSYİH'ye Oranı } \\
\text { Devletin Yurtdışı Borçlarının GSYİH'ye Oranı } \\
\text { Finansal Şirketlerin Toplam Borcunun GSYİH'ye Oranı } \\
\text { Finansal Olmayan Şirketlerin Toplam Borcunun GSYİH'ye Oranı }\end{array}$ \\
\hline Erişilebilirlik & $\begin{array}{l}\text { İlk } 10 \text { En Büyük Hisse Senedi Dışarıda Bırakıldıktan Sonraki Piyasa } \\
\text { Hacmi Oranı } \\
\text { Borç Veren Kuruluşların Sayısı (Yerli, Yabancı, Finansal ve Finansal } \\
\text { Olmayan) }\end{array}$ \\
\hline Verimlilik & $\begin{array}{l}\text { Hisse Senedi Piyasası Devir Oranı (Hisse Senetlerinin Piyasa Hacmine } \\
\text { Oranı) }\end{array}$ \\
\hline
\end{tabular}

\subsection{Metodoloji}

Bu çalışmada finansal gelişim endeksi oluşturulurken, OECD (2008) Kompozit Endeks Oluşturma Metodları Kılavuzu'ndaki prosedürler göz önünde bulundurulmuştur. Buna göre endeks, literatürdeki üç basamaklı standart yaklaşım izlenerek çok boyutlu verileri tek bir özet endeksine indirgenmesiyle elde edilmiştir. Endeksin birden fazla adımda oluşturulmasının sebebi çok boyutlu olan verileri bir sonuç endeksinde toparlayabilmektir. Bu bağlamda öncelikli olarak ilk basamakta değişkenlerin normalleştirilmesi, ikinci basamakta normalleştirilen değişkenlerin ana faktörlerine göre bir araya getirilerek alt endekslerin oluşturulması ve son olarak da bütün alt endekslerin bir araya getirilerek final endeksinin oluşturulması hedeflenmiştir.

Finansal gelişmişliğin belirlenebilmesi için finansal gelişmişliğin farklı boyutlarını inceleyen 9 adet endeks IMF'nin ilk kez 2012 yılında yayımladığı finansal gelişmişliğin boyutlarını özetleyen piramitten yararlanılarak oluşturulmuştur. Bu bahsi geçen piramide göre finansal gelişmişlik finansal kurumlar ve finansal piyasaların oluşturduğu iki ana alanda incelenmektedir. Bu iki alan ise derinlik, erişilebilirlik, verimlilik olmak üzere üç boyutta incelenmektedir. Bu çalışmada ilk olarak hem finansal kurumların hem de finansal piyasaların derinlik, erişilebilirlik ve verimliliklerini belirleyen 6 alt endeks oluşturulmuştur. İkinci adımda bu alt endeksler finansal kurumlar ve finansal piyasalar olmak üzere iki endeks altında bir araya getirilmiştir. Son adımda ise nihai gelişmişlik endeksini oluşturmak için bu iki endeks bir araya getirilmiş ve Türkiye'nin ve diğer gelişmekte olan ülkelerin finansal gelişmişlik endeksleri elde edilmiştir.

Aşağıda verilmiş olan piramit 6 alt-endeksten başlayarak finansal kurumların ve piyasaların derinlik, erişilebilirlik ve verimliliklerini ölçmek için oluşturulan endeksleri göstermektedir. Bu endeksler Finansal 
Kurumların Derinliği (FKD), Finansal Kurumların Erişilebilirliği (FKE), Finansal Kurumların Verimliliği (FKV), Finansal Piyasaların Derinliği (FPD), Finansal Piyasaların Erişilebilirliği (FPE) ve Finansal Piyasaların Verimliliğidir (FPV). Bu 6 alt indeks iki gruba ayrılarak üst seviye Finansal Kurumlar (FK) ve Finansal Piyasalar (FP) endeksleri oluşturulmuştur. Bu iki endeks finansal kurumların ve finansal piyasaların ayrı ayrı olmak üzere toplamda finansal gelişmişlik düzeylerini ortaya çıkarmıştır. Son basamakta ise FK ve FP endeksleri bir araya getirilerek ülkelerin tüm finansal gelişmişlik seviyesini ortaya koyan Finansal Gelişmişlik (FG) endeksi oluşturulmuştur.

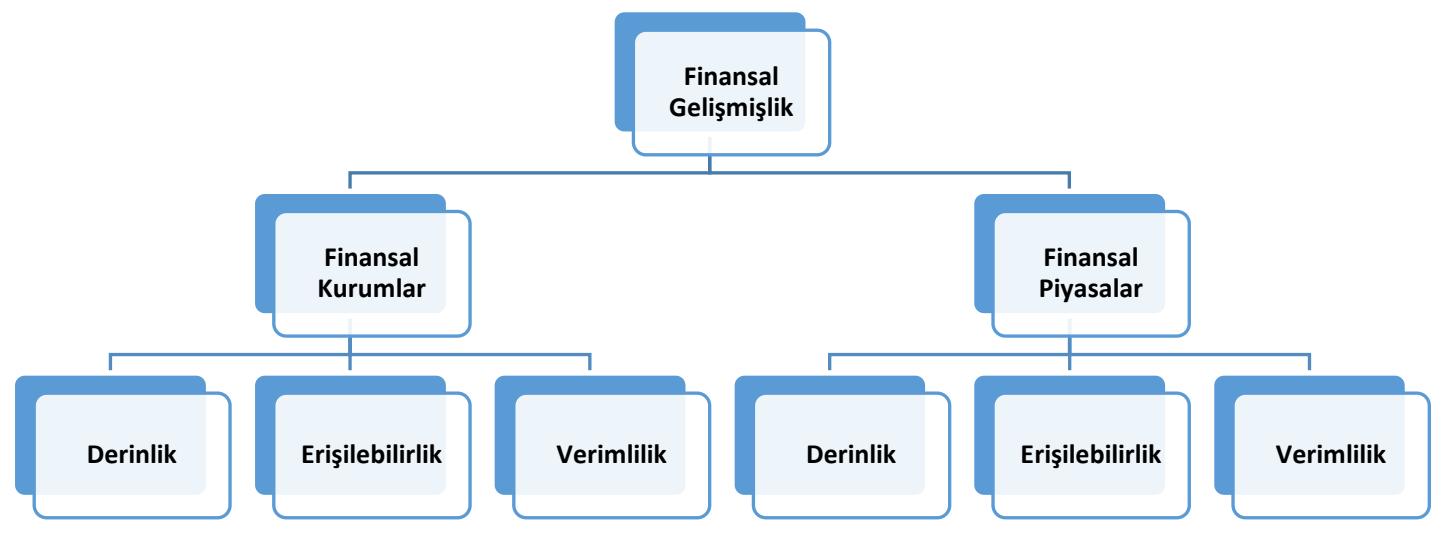

Şekil 1. Finansal Gelişmişlik Endeksi Piramidi Kaynak: Cihak et al. (2012)

Çalışmaya dâhil edilen temel değişkenler seçilirken, finansal sistemin birçok farklı yönünü kapsamasına ve aynı zamanda ülkeler için yeterli veri setini içeriyor olmasına dikkat edilmiştir. Finansal piyasalar için oluşturulan gelişmişlik endeksi hisse senedi piyasaları ve borç piyasalarının gelişmişliğine odaklanmaktadır. Derinlik endeksinde yer alan indikatörler hisse senedi piyasasının büyüklüğü ile birlikte işlem gören hisse senetlerini de göz önünde bulundurarak piyasanın ne kadar aktif olduğunu da dikkate almaktadır. İlk 10 en büyük hisse senedi dışarıda bırakıldıktan sonraki piyasa hacmi oranı piyasalara erişimin derecelendirilebilmesi için vekil olarak kullanılmıştır. Buna göre fazla konsantre bir piyasa yeni giren ya da daha küçük olan hisselere erişimin zor olacağını gösterecektir (Svirydzenka, 2016). Finansal piyasaların etkinliği için kullanılan işlem gören hisse senetlerinin değerinin piyasanın hacmine oranı yani devir oranı büyüdükçe piyasanın likidite durumunun güçlü olduğu ve piyasanın etkin olduğu anlamı çıkarken düşük seviyedeki devir oranı piyasanın etkin olmadığı sonucunu vermektedir. Endekslerin oluşturulması için kullanılan tüm değişkenler veri kısmında listelenmiştir.

\subsubsection{Değişkenlerin Normalleştirilmesi}

Değişkenleri 1 ile 0 arasında normalleştirmeden önce ekstrem değerlerin normalleştirilen değerler üzerindeki anormal etkilerini önleyebilmek ve daha sağlıklı bir analiz elde edebilmek için yüzde 5 ve yüzde 95'lik dilimlerde yer alan gözlemler dışarıda bırakılmışlardır. Bu aşamadan sonra farklı değerlere sahip olan değişkenleri 0 ile 1 aralığında toplayabilmek için aşağıda detaylı formülleri verilen min-max prosedürü kullanılmıştır. Buna göre $I_{x}$ yani $x$ verisinin 0 ile 1 arasına dönüştürülmüş değeri o değişken için gözlemlenen minimum değerin değişkenden çıartılıp bütün ülkeler arasında ve analiz edilen zaman aralığında gözlemlenen maksimum değer ile minimum değerin arsındaki farka bölünmesi ile bulunmuştur. Böylelikle analiz edilen ülkeler ve zaman aralığı için gözlemlenen en yüksek değer 1 iken en küçük değer 0 olarak işlenmiş, değişkenlerin buna bağlı olarak aldıkları değer 0 ile 1 arasında belirlenmiş olmuştur. Analizde kullanılan bazı değişkenlerde yüksek çıkan değereler kötü performansa işaret ettiği için bu değişkenlerin finansal gelişmişlik üzerindeki etkilerinin tam tersi etkilerini ortaya koyabilmek için 2 numaralı formül kullanılmıştır. Böylelikle bu formül sonucunda ortaya çıkan yüksek değerlerin finansal gelişmişliğe olumlu katkısının olması sağlanmıştır.

$\begin{aligned} I_{x} & =\frac{x-x_{\min }}{x_{\max }-x_{\min }} \\ I_{x} & =1-\frac{x-x_{\min }}{x_{\max }-x_{\min }}(2)\end{aligned}$ 


\subsubsection{Alt Endekslerin Bir Arada Toplanması}

Çalışmada kullanılan değişkenler, Şekil 1'de gösterilen piramidin altında bulunan altı alt endeks olacak şekilde toplanmıştır. Temel bileşenler analizi ile elde edilen serilerin ağırlıklı lineer ortalaması olan bu toplam, her bir alt dizinin katkısını belirli alt indeksindeki varyasyona yansıtmaktadır. Tüm alt endeksler daha sonra Denklem 3 ve 4'te gösterildiği gibi 0-1 aralığında kalacak şekilde bir araya getirilmiştir.

$$
\begin{aligned}
& F K_{j}=\sum_{i=1}^{n} w_{i} I_{i} \\
& F P_{j}=\sum_{i=1}^{n} w_{i} I_{i}
\end{aligned}
$$

Denklem 3 ve $4^{\prime}$ te verilen $F K_{j}$ ve $F P_{j}$ finansal kurumların derinliğini, erişilebilirliğini ve verimliliğini, finansal piyasaların derinliğini, erişilebilirliğini ve verimliliğini temsil etmektedir.

$$
\begin{aligned}
& F K=\sum_{j=1}^{n} w_{j} F_{j} \\
& F P=\sum_{j=1}^{n} w_{j} F P_{j} \\
& F G=w_{F I} F K+w_{F M} F P
\end{aligned}
$$

Denklem 5, 6 ve 7'de gösterildiği üzere, alt endeksler yukarıda açıklanan yol kullanılarak üst endekslerde toplanmıştır. Finansal kurumlar, finansal piyasalar ve finansal derinlik endeksleri daha sonra yeniden normalleştirme yapılarak 0-1 aralığında değerlendirilmiştir.

\subsection{3 Ă̆ırlıklandırma}

Bu çalışmadaki endeksler Temel Bileşenler Analizi kullanılarak hesaplanmıştır. Bu analiz, bireysel göstergeler için ortak olan bilginin mümkün olduğu kadar çok olduğu birleşik bir gösterge oluşturmak için ortak olanları bir araya getirmektedir. Buradaki düşünce, mümkün olan en küçük sayıda faktör kullanılarak gösterge setindeki olası en yüksek değişimi hesaba katmaktır. Bunun sonucunda, bileşik endeks veri kümesinin boyutuna bağlı olmadan, verilerin istatistiksel boyutlarına dayanmaktadır. Alt endeksler, normalleştirilmiş serilerin ağırlıklı ortalamaları olarak oluşturulmuştur. Ağırlıklar bu serilerin temel bileşenler analizinden elde edilen karesel faktör bileşenleridir. Faktör bileşenleri, gözlemlenen değişkenleri ana bileşenlerle ilişkilendiren katsayılardır. Faktör bileşenlerinin karesi ise, faktör tarafından açılanmış olan göstergenin toplam birim varyansının oranını temsil etmektedir. Verilerdeki yaygın varyasyon yönüne daha fazla katkıda bulunan seri, daha fazla ağırlık kazanmaktadır.

\section{4- TÜRKIYE VE DİĞER GELIŞMEKTE OLAN ÜLKELERIN FINANSAL GELIŞMIŞLIK SEVIYYLERI}

Bu çalışmada, son 12 yıllık dönemdeki (2005-2016) değişkenlerin analizi ile Türkiye'nin de içinde bulunduğu 5 gelişmekte olan ülkenin finansal gelişmişlik değerleri belirlenmiştir. Tablo 2 ve Tablo 3 öncelikli olarak finansal gelişmişlik seviyesini belirleyebilmek için kullanılan alt endekslerin her ülke için değerlerini göstermektedir.

Tablo 2. Ülkelere Göre Finansal Kurumların Derinlik, Erişilebilirlik ve Verimlilik Sıralaması

\begin{tabular}{|c|l|l|l|l|l|l|l|l|}
\hline \multicolumn{2}{|c|}{$\begin{array}{c}\text { Finansal Kurumların } \\
\text { Derinliği }\end{array}$} & \multicolumn{3}{c|}{$\begin{array}{c}\text { Finansal Kurumların } \\
\text { Erişilebilirliği }\end{array}$} & \multicolumn{3}{c|}{ Finansal Kurumların Verimliliği } \\
\hline 1 & Malezya & 0.994 & 1 & Brezilya & 0.923 & 1 & Malezya & 0.975 \\
2 & Güney Afrika & 0.935 & 2 & Türkiye & 0.892 & 2 & Güney Afrika & 0.942 \\
3 & Türkiye & 0.905 & 3 & Malezya & 0.854 & 3 & Türkiye & 0.869 \\
4 & Brezilya & 0.900 & 4 & Polonya & 0.835 & 4 & Polonya & 0.792 \\
5 & Polonya & 0.887 & 5 & Güney Afrika & 0.730 & 5 & Brezilya & 0.742 \\
\hline
\end{tabular}

Tablo 2'de Brezilya, Güney Afrika, Malezya, Polonya ve Türkiye için finansal kurumların derinlik, erişilebilirlik ve verimlilik sıralaması verilmiştir. Finansal kurumların derinliği sıralamasına bakıldığında, Malezya'nın 0.994 ile en yüksek değere sahip olduğu görülmektedir. Onu 0.935'lik değerle Güney Afrika izlemektedir. Türkiye'nin değerinin ise 0.905 olduğu görülmektedir. Brezilya 0.900 'lük değerle sıralamanın 
dördüncü basamağında yer alırken Polonya 0.887 ile son basamakta yer almaktadır. Buna karşı finansal kurumların erişilebilirliği sıralamasına bakıldığında, Brezilya' nın 0.923 değerleriyle tablonun ilk sırasında yer aldığ1 görülmektedir. Türkiye 0.892 'lik değeriyle finansal kurumların erişilebilirliği sıralamasında ikinci sırada yer alırken, finansal kurumların derinliği sıralamasında ilk sırada yer alan Malezya bu endekste 0.854 değeriyle üçüncü sırada bulunmaktadır. Finansal kurumların derinliği alt endeksine göre son sırada bulunan Polonya ise finansal kurumların erişilebilirliği sıralamasında 0.835 değeriyle dördüncü basamakta yer alırken, Güney Afrika 0.730 ile sıralamanın sonunda bulunmaktadır. Finansal kurumların verimliliği alt endeksi incelendiğindeyse, sıralamanın en üstünde finansal kurumların derinliği alt endeksinde olduğu gibi 0.975 ile Malezya'nın yer aldığı göze çarpmaktadır. Malezya'yı 0.942 değeriyle Güney Afrika ve 0.869'luk değerle Türkiye takip etmektedir. Polonya'ya bakıldığında 0.792 değeriyle sıralamanın dördüncü basamağında yer alırken, Brezilya 0.742 ile son basamakta bulunmaktadır.

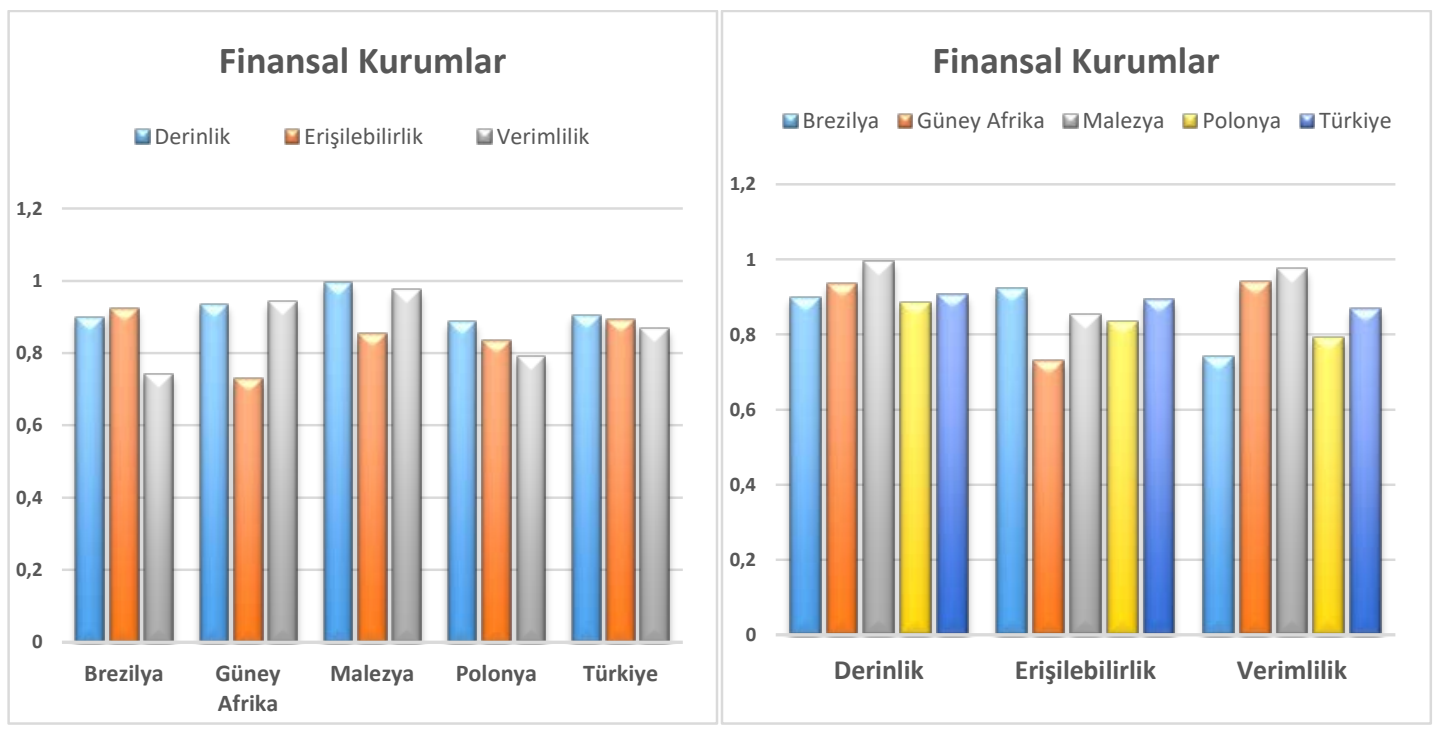

Grafik 1. Finansal Kurumların Derinlik, Erişilebilirlik ve Verimlilikleri

Tablo 2' de yer alan değerler yukarıdaki grafikte bir araya getirilmiş ve ülkelerin hem finansal kurumların derinliği, erişilebilirliği ve verimliliği alanlarında kendi içlerinde nasıl farklılıklar gösterdiği gözler önüne serilmiş hem de bu alanlarda ülkeler arasındaki farklılıkların daha iyi görülebilmesi sağlanmıştır.

Tablo 3 Brezilya, Güney Afrika, Malezya, Polonya ve Türkiye finans piyasalarının derinlik, erişilebilirlik ve verimlilik sıralamasını göstermektedir. Buna göre, finansal piyasaların derinliği alt endeksi incelendiğinde, finansal kurumların derinliği alt endeksi sıralamasında olduğu gibi Malezya'nın 0.994 değeriyle listenin ilk sırasında yer aldığı görülmektedir. Sıralamanın ikinci basamağında ise 0.951 değeriyle Türkiye yer almaktadır. Brezilya 0.902 değeriyle üçüncü sırada bulunurken, Güney Afrika 0.846 ile dördüncü sırada yer almaktadır. Polonya ise finansal kurumların derinliği sıralamasında olduğu gibi finansal piyasaların derinliği sıralamasında da en alt basamakta yer almıştır. Finansal piyasaların erişilebilirliği sıralamasında bakıldığında, Türkiye'nin 0.942 değeriyle en üstte yer aldığı görülmektedir. Brezilya 0.920 ile ikinci sırada bulunurken, onu sırasıyla 0.896, 0.854 ve 0.803 değerleriyle Malezya, Polonya ve Güney Afrika takip etmektedir.

Tablo 3. Ülkelere Göre Finansal Piyasaların Derinlik, Erişilebilirlik ve Verimlilik Sıralaması

\begin{tabular}{|l|l|l|l|l|l|l|l|l|}
\hline \multicolumn{3}{|c|}{$\begin{array}{c}\text { Finansal Piyasaların } \\
\text { Derinliği }\end{array}$} & \multicolumn{3}{c|}{$\begin{array}{c}\text { Finansal Piyasaların } \\
\text { Erişilebilirliği }\end{array}$} & \multicolumn{3}{c|}{ Finansal Piyasaların Verimliliği } \\
\hline 1 & Malezya & 0.994 & 1 & Türkiye & 0.942 & 1 & Türkiye & 0.972 \\
2 & Türkiye & 0.951 & 2 & Brezilya & 0.920 & 2 & Malezya & 0.963 \\
3 & Brezilya & 0.902 & 3 & Malezya & 0.896 & 3 & Brezilya & 0.914 \\
4 & Güney Afrika & 0.846 & 4 & Polonya & 0.854 & 4 & Güney Afrika & 0.876 \\
5 & Polonya & 0.829 & 5 & Güney Afrika & 0.803 & 5 & Polonya & 0.799 \\
\hline
\end{tabular}

Finansal piyasaların verimliliği alt endeksi incelendiğinde, finansal kurumların verimliliği sıralamasında üçüncü sırada yer alan Türkiye'nin, bu kez 0.972 değeriyle ilk sırada bulunduğu göze çarpmaktadır. 
Türkiye'yi 0.963 'lük değerle Malezya takip etmektedir. Finansal kurumların verimliliği alt endeksinde en alt basamakta yer alan Brezilya ise, finansal piyasaların verimliliği endeksinde 0.914 değeriyle üçüncü sırada yer almaktadır. Güney Afrika 0.876 ile dördüncü, Polonya ise 0.799 ile son sırada yer almıştır. Şekil 2 hem ülkelerin kendi içlerinde derinlik, erişilebilirlik ve verimlilik alanlarında nasıl farklılıklar gösterdiğini hem de bu alanlarda ülkeler arasında nasıl farklılıklar olduğunu göstermektedir.
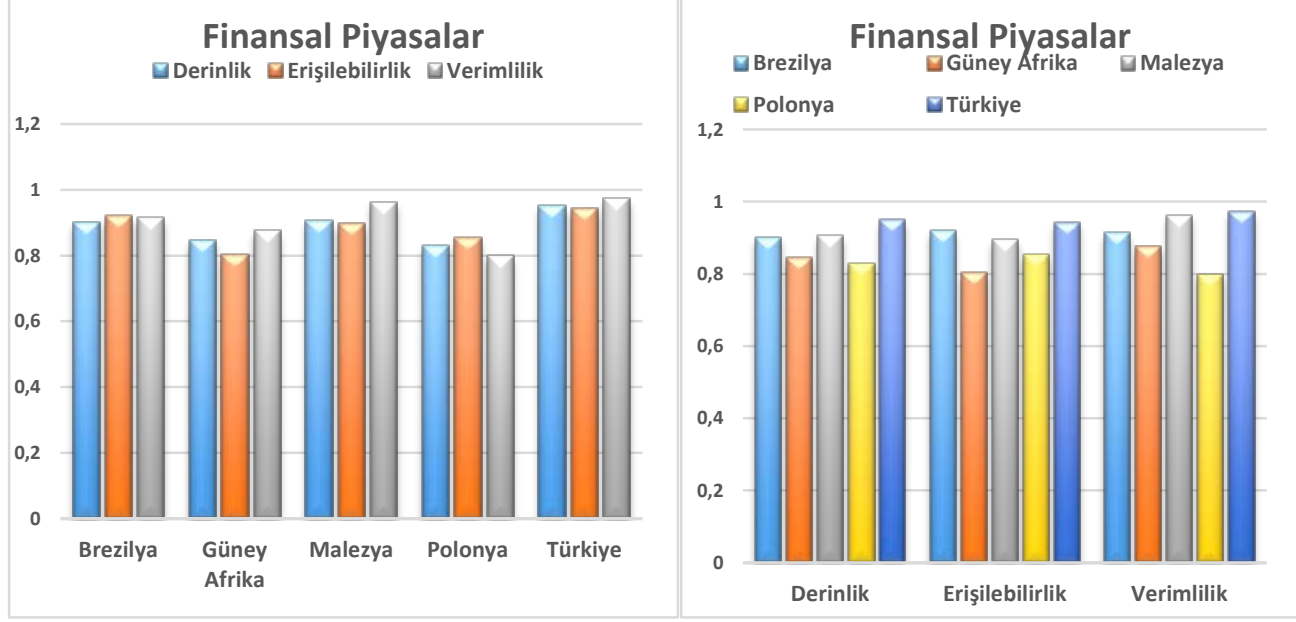

Şekil 2. Finansal Piyasaların Derinlik, Erişilebilirlik ve Verimlilikleri

Tablo 4, Tablo 2 ve Tablo 3'te yer alan alt endekslerin bir araya getirilmesiyle elde edilen Finansal Kurumlar ve Finansal Piyasalar endekslerini ve Finansal Kurumlar ve Finansal Piyasalar endekslerinin bir araya getirilmesiyle elde edilen nihai Finansal Gelişmişlik Endeksi sonuçlarını vermektedir. Finansal kurumların alt endekslerine göre en başarılı değerlere sahip olan ülke Malezya -hem finansal kurumların derinliği hem de verimliliği sıralamasında listenin en başında yer almaktadır- Finansal Kurumlar Endeksi'ne göre beş gelişmekte olan ülke arasında en gelişmiş finansal kurumlara sahip çıkmıştır. Malezya'yı Türkiye ve Güney Afrika takip etmektedir. Brezilya ve Polonya ise sırasıyla listenin son basamaklarında yer almıştır. Türkiye'nin finansal piyasaların derinlik, erişilebilirlik ve verimlilik alt endekslerinde, finansal kurumların derinlik, erişilebilirlik ve verimlilik alt endekslerine göre daha başarılı bir performans sergilediği göze çarpmaktadır. Buna göre Tablo 4'te verilen Finansal Piyasalar Endeksi sıralamasına bakıldığında Türkiye'nin bu beş ülke arasından en gelişmiş en başarılı finansal piyasalara sahip olduğu görülmektedir. Türkiye'yi sırasıyla Malezya, Brezilya, Güney Afrika ve Polonya izlemektedir.

Finansal Kurumlar ve Finansal Piyasalar endekslerinin bir araya getirilmesi ile elde edilen Finansal Gelişmişlik Endeksi bu beş ülkenin nihai olarak finansal gelişmişlik derecelerini ve sıralamalarını gözler önüne sermektedir. Buna göre Malezya incelenen beş gelişmekte olan ülke arasında finansal gelişmişliği en yüksek ülke olarak belirlenirken Malezya'yı Türkiye takip etmiştir. Geri kalan üç ülke arasında sıralama ise Brezilya, Güney Afrika ve Polonya şeklinde olmuştur. Hesaplanan endekslerin değerlerinin daha ilk alt endeksten itibaren ülkeler arasında birbirlerine çok yakın olması aslında ülkeler arasında çok ciddi farklılıkların olmadığını gözler önüne sermiş, nihai gelişmişlik endeksinin hesaplanması sonucunda ise ülkelerin sıralamaları yukarıda bahsedildiği gibi şekillenmiştir.

Tablo 4. Ülkelerin Gelişmişlik Dereceleri ve Sıralamaları

\begin{tabular}{|l|l|l|l|l|l|l|l|l|}
\hline \multicolumn{2}{|l|}{ Finansal Kurumlar Endeksi } & \multicolumn{3}{|c|}{ Finansal Piyasalar Endeksi } & \multicolumn{3}{|c|}{ Finansal Gelişmişlik Endeksi } \\
\hline 1 & Malezya & 0,969 & 1 & Türkiye & 0,950 & 1 & Malezya & 0,960 \\
2 & Türkiye & 0,903 & 2 & Malezya & 0,944 & 2 & Türkiye & 0,934 \\
3 & Güney Afrika & 0,881 & 3 & Brezilya & 0,925 & 3 & Brezilya & 0,903 \\
4 & Brezilya & 0,866 & 4 & Güney Afrika & 0,869 & 4 & Güney Afrika & 0,890 \\
5 & Polonya & 0,844 & 5 & Polonya & 0,848 & 5 & Polonya & 0,857 \\
\hline
\end{tabular}

\section{5- SONUÇ}


Küreselleşen dünyada ülkelerin finansal gelişmişlik seviyeleri hem potansiyel yatırımcları çekebilmek için hem de ekonomik ve finansal istikrarı sağlayabilmek için büyük önem kazanmıştır. Bu sebeple bir yandan ülkeler finansal gelişmişlik seviyelerini artırmanın yöntemlerini aranırken diğer yandan gerek yatırımcılar gerekse de akademisyenler ülkelerin finansal gelişmişlik seviyelerini tespit etmeye çalışmışlardır. Bu bağlamda finansal gelişmişlik seviyesinin belirlenmesi birçok çalışmaya konu olmuş ve ülkelerin finansal gelişmişliklerini tespit ettiği iddia edilen birçok metot geliştirilmiştir. Bugün gelişmişlik seviyesini belirlerken kapsamlı verilerle birçok endeks oluşturup bunları bir araya getiren Geniş Kapsamlı Finansal Gelişmişlik Endeksi finans alanının hemen hemen bütün alanlarını kapsaması ve bu alanların endekste sayısal olarak temsil edilmesi anlamıyla en güvenilir endekslerden biri olarak tanımlanabilir.

Bu çalışmada, Türkiye'nin hem siyasi hem ekonomik anlamda nazaran daha istikrarlı olduğu 2005-2016 yılları arasında kalan döneme ait veriler ile finansal gelişmişlik seviyesi tespit edilmiştir. Bu süreçte uluslararası yatırımcıların Türkiye'nin alternatifi olarak değerlendirdiği dört gelişmekte olan ülke de, Brezilya, Güney Afrika, Malezya ve Polonya, çalışmaya dâhil edilmiş ve bu beş ülkenin finansal gelişmişlik seviyeleri karşılaştırılmıştır. Çıkan sonuç Türkiye'nin finansal piyasalarının gelişmişliğinin bu dört ülkeden de ileri seviyede olduğunu gözler önüne sererken, finansal kurumlar konusunda bir takım sıkıntıları olmasına rağmen gelişmişlik seviyesine göre ikinci sırada olduğunu ortaya koymuştur. Nihai Finansal Gelişmişlik Endeksi ise Türkiye'nin Malezya'ya göre daha düşük bir finansal gelişmişlik seviyesine sahip olmasına rağmen Brezilya, Güney Afrika ve Polonya'dan daha ileri bir noktada olduğunu göstermiştir.

Farklı alanlardaki farklı sıralamalar aslında finansal gelişmişliğin tek bir sıralamadan ya da sonuçtan ibaret olmadığını, ülkelerin bazı alanlarda gelişmişken bazı alanlarda gelişmeye muhtaç olabileceğini göstermiştir. Buna göre Türkiye rakipleri arasında finansal piyasalar olarak her ne kadar ileride olsa da finansal kurumlar endeksinde aynı başarıyı gösterememiş, sonuç olarak da nihai gelişmişlik endeksinde ikinci sırada kalmıştır. Bu noktada politika yapıcıların finans piyasalarının düzenlenmesine daha yoğun ilgi göstermesi ile başarılı sonuçlar alındığı fakat özelde kurumların da ilgiye ve geliştirilmeye ihtiyaçları olduğu yorumu yanlış olmayacaktır. Bir başka önemli husus olan kurum ve piyasa endekslerinin kendi içlerinde de detaylı olarak derinlik, erişilebilirlik ve verimlilik bağlamlarında analiz edilerek politika yapıcılar tarafından temel sıkıntıların tespit edilmesinin gerekliliği de bu çalışma ile net bir şekilde gün yüzüne çıkmıştır.

Sonuç olarak, Türkiye'nin finansal gelişiminin en yeni ve kapsamlı endeksin kullanılması ile tespit edilmesi ve gelişmekte olan ülkeler arasındaki yerinin belirlenmesi ile birlikte hem politika yapıcılara yol gösterici, hem de hesaplanan endeksin daha mikro ölçekte analizlere tabi tutulması ile birlikte birçok çalışmaya öncü olunacak temel bir çalışma ortaya konmuştur.

\section{Kaynakça}

Aizenman, J., Jinjarak, Y. ve Park, D. (2015). Financial Development and Output Growth in Developing Asia and Latin America: A Comparative Sectoral Analysis, Cambridge, Massachusetts: National Bureau of Economic Research Working Paper 20917.

Apergis, N., Filippidis, I. ve Economidou, C. (2007). Financial Deepening and Economic Growth Linkages: A Panel Data Analysis, Review of World Economics, 143, 179-198.

Arcand, J. L., Berkes, E. ve Panizza, U. (2012). Too Much Finance?, Washington, DC: IMF Working Paper 12/161.

Aslan, Ö. ve Küçükaksoy, İ. (2006). Finansal Gelişme ve Ekonomik Büyüme İlişkisi: Türkiye Ekonomisi Üzerine Ekonometrik Bir Uygulama, Ekonometri ve İstatistik, 4, 12-28.

Brandon, C. ve Tang, T. (2010). Do Investors Value SEO Lockup Agreements?, Journal of Business Research, 68, 314-321.

Calderon, C. ve Liu, L. (2003). The Direction of Causality Between Financial Development and Economic Growth, Journal of Development Economics, 72, 321-334.

Čihák, M., Demirgüç-Kunt, A., Feyen, E. ve Levine, R. (2012). Benchmarking Financial Development Around the World, Washington, DC: World Bank Policy Research Working Paper 6175.

Çetintaş, H. ve Barışık, S. (2003). Banks, Stock Market and Economic Growth: Cointegration and Causality Analysis Case of Turkey (1989-2000), ISE Review, 7, 1-17. 
D. Emin $11 / 3$ (2019) $2205-2215$

Dabla-Norris, E. ve Srivisal, N. (2013). Revisiting the Link between Finance and Macroeconomic Volatility, Washington, DC: IMF Working Paper 13/29.

Demirgüç-Kunt, A. ve Levine, R. (2009). Finance and Inequality: Theory and Evidence, Annual Review of Financial Economics, 1(1), 287-318.

Halıcioğlu, F. (2007). The Financial Development and Economic Growth Nexus for Turkey, Munich: MPRA Discussion Paper 3566.

Hicks, J. (1969). A Theory of Economic History. In: R. W. Goldsmith (Ed.), Financial Structure and Development, (pp. 106-131). New Haven, CT: Yale U. Press.

Goldsmith, R. (1969). Financial Structure and Development, Yale University Press, New Haven.

Kar, M. ve Ağır, H. (2006). Türkiye'de Beşeri Sermaye ve Ekonomik Büyüme İlişkisi: Eşbütünleşme Yaklaşımı ile Nedensellik Testi, 1926-1994, Selçuk Üniversitesi İktisadi ve İdari Bilimler Fakültesi Sosyal ve Ekonomik Araştırmalar Dergisi, 11, 51-68.

King, R. G. ve Levine, R. (1993). Finance, Entrepreneurship, and Growth: Theory and Evidence, Journal of Monetary Economics, 32, 513-542.

Levine, R. (1997). Financial Development and Economic Growth Financial Development and Economic Growth: Views and Agenda, Journal of Economic Literature, 35, 688-726.

Levine, R. (2005). Finance and Growth: Theory and Evidence. In: P. Aghion \& S. Durlauf (Ed.), Handbook of Economic Growth, (pp. 865-934). Amsterdam: Elsevier.

Levine, R., Loayza, N. ve Beck, T. (2000). Financial Intermediation and Growth: Causality and Causes, Journal of Monetary Economics, 46, 31-77.

Lucas, R. E. (1988). On the Mechanics of Economic Development, Journal of Monetary Economics, 22, 3-42.

Luintel, K. ve Khan, M. (1999). A Quantitative Reassessment of the Finance-Growth Nexus: Evidence from, Multivariate VAR, Journal of Development Economics, 60, 381 -405.

Rajan, R. G. ve Zingales, L. (1998). Financial Dependence and Growth, American Economic Review, 88, 559-586.

Robinson, J. (1952). The Generalisation of the General Theory in: The Rate of Interest and other Essays. London: McMillian.

Schumpeter, J.A. (1912). The Theory of Economic Development: An Inquiry into Profits, Capital, Credit, Interest and the Business Cycle. London: Transaction Publishers.

Svirydzenka, K. (2016). Introducing a New Broad-based Index of Financial Development. Washington, DC: IMF Working Paper 16/5.

Unalmis, D. (2002). The Causality Between Financial Development and Economic Growth: The Case of Turkey. Ankara: The Central Bank of the Republic of Turkey Working Papers 0203. 